\title{
Market Competitiveness of the Czech Economy in the Era of Globalization: Some New Empirical Insights
}

\author{
Nahanga Verter \\ Department of Regional and Business Economics, Mendel University in Brno \\ Email: xverter@mendelu.cz \\ Christian Nedu Osakwe \\ Faculty of Management and Economics, Tomas Bata University in Zlin \\ Email: osakwe@fame.utb.cz
}

Doi:10.5901/mjss.2015.v6n1p268

\begin{abstract}
The paper deals with market competitiveness and the performance of the Czech economy in the era of globalization, using annual time series, which spans from 1993 to 2012. Econometric techniques such as the Granger causality test and impulse response function were employed in order to verify the interactions of the Czech Republic market size (real GDP per capita), trade openness, inward FDI, REER and globalization dynamics. The findings provide a robust evidence that globalization fosters market size, growth within the context of the Czech economy. The more globalized the Czech economy becomes, the more likely it would experience real GDP per capita.
\end{abstract}

Keywords: Czech economy, globalization, Granger causality, innovation accounting, market size;

\section{Introduction}

The rapid expansion in the movement of goods, services and investments across national borders in recent decades has been reshaping the socioeconomic policies and political situations in many countries worldwide. While most countries across the continents have embraced globalization, in general, and global trade and investment, in particular, others have partially embraced it.

Economists, world organizations and scientists have a number of arguments in favour of global trade and market competitiveness within countries. They argued that, trade brings goods and services to the nations. It leads to the diversity of goods and services that increase choices for the population, trade also allows market competitiveness that leads to product quality and efficient exchanges and accelerate economic growth and development in countries (Ocampo and Martin, 2003; Stiglitz and Charlton, 2007).

There has been an increasing interest in anti-competitive practices that distort market access and competition among countries (Lee, 2004). The discussion of market access and anti-competitive practices in the era of globalization has drastically risen since the creation of the World Trade Organization (WTO) as a body for trade negotiations, policies and rules. The organization has made progress in the expansion of the world trade and financial flows through the reduction of trade barriers distort free exchanges and market competitiveness, such as the import tariffs, quotas and subsidies and other related trade distortions that undermine competitiveness.

Market competitiveness is considered as a vital ingredient for production and trade in the economy. The Czech Republic just like other countries, most especially central and eastern European countries stand a chance of rapidly benefiting from global trade competition through exports of goods and services, and foreign financial flows.

The integration of national economies into the global economy in recent decades has brought opportunities and challenges for domestic firms in emerging markets like the Czech Republic to innovate and improve their competitive positions. Some of these challenges and opportunities have intensified through increased in market competitions among overseas firms (Gorodnichenko, Svejnar and Terrell, 2008). For instance, the unrestricted movement of capital, the socalled FDI by transnational corporations (TNCs) helps to improve the competitive position of both the recipients and the investing economies (OECD, 2008). This source of external income appears to play an important role in the Czech economy since 1993 (Marek and Baun, 2010). 
Some studies have empirically determined the relationship between globalization and competitiveness in some countries. For instance, Salvatore (2010) find a positive relationship between globalization, international competitiveness and growth, using data from the KOF globalization and the IMD global competitiveness indices (2009) for 52 countries. Similarly, Adamkiewicz-Drwillo (2012) examine the effects of globalization on international competitiveness, using data from the World Economic Forum and KOF globalization in 138 countries. The results showed a connection between globalization and competitiveness in the countries investigated. Nečadova and Scholleová (2012) conducted primary research to determine competitiveness and innovation of the Czech business level. They discovered that many firms in the country regarded flexibility and innovation as a major vehicle to maintain a competitive advantage in the access market.

Bretschger and Hettich (2005) studies the different effects of globalization on the corporate capital tax competition in the 12 OECD countries, and the results show that the globalization has a negative effect on capital tax rates. Their findings lend credence to the tax competition theory and, hence, the so-called "efficiency hypothesis" of globalization, which says that globalization decreases government sector size and its capacity to finance welfare initiatives.

Lee (2010) examine the impact of globalization on the business cycle movement of individual states in the US states with the rest of the country's economy, using a panel data over the period 1990-2005. His findings showed that global integration, through trade or FDI flows, raises a state economy's business cycle synchronization with other regions of the US and the world economy. Yun (2004) determined whether or not, market competition has contributed to increasing productivity in Korea, by focusing on the impact of product market competition on productivity, using manufacturing firms' data. The results showed that changes in the number of firms would be an important source that triggers market competitiveness and higher productivity. Zeren and Ari (2013) determine if there is a connection between trade openness and economic growth in G7 countries between 1970 and 2011. Their results showed a bidirectional causality between the variables. They concluded that as openness increases in the $\mathrm{G} 7$ countries, growth also increases.

Published empirical works within the context area of the study's subject matter in the Czech Republic are scarce, hence, the motivation for the study. This study is an attempt empirically to verify market competitiveness and the performance of the Czech economy in the era of globalization.

The remaining part of this paper is organized as follows: Section 2 looks at the nexus between globalization and competitiveness. Section 3 presents data with the analytical framework. Section 4 presents the empirical results and interpretation. Finally, section 5 concludes the study.

\section{Globalization and Competitiveness}

There are various ways of measuring how globalized a country is in terms of its economic, social, political and other indicators. One such was coined by Dreher (2006) and Dreher et al. (2008) which is known as the KOF index of globalization ${ }^{1}$ The KOF index provides a yardstick for measuring levels of globalization across countries.

Unarguably, there are numerous bodies that measure countries' competitiveness around the globe, but we chose to analyse Czech competitiveness with reference to the Institute for Management Development (IMD) World Competitiveness Yearbook ${ }^{2}$ and the Global Competitiveness Index (GCl) ${ }^{3}$ by the World Economic Forum (WEF).

\footnotetext{
1 Dreher et al. 2008. KOF Globalization index covers 123 countries and includes 23 variables and portrays the economic, social and political dimension of globalization. Each of these three dimensions has further divided into sub dimensions. For instance, economic globalization is described by actual flows (trade, FDI, portfolio investment and income payments to foreign nationals, each measured as a percentage of GDP).

2 IMD (2013) World Competiveness index and ranking is based on 323 criteria (2/3 hard facts, 1/3 executive opinion survey with 4,000 responses from 60 countries). The data are grouped into 4 main factors: economic performance (76 criteria, i.e. domestic economy, international trade, international investments, employment, prices), government efficiency, business efficiency (67 criteria, i.e. productivity and efficiency, labour market, finance, management practices) and infrastructure.

${ }^{3}$ WEF (2013) $\mathrm{GCl}$ is a comprehensive tool that measures the microeconomic and macroeconomic foundations of national competitiveness. It is composed of 12 "pillars".
} 


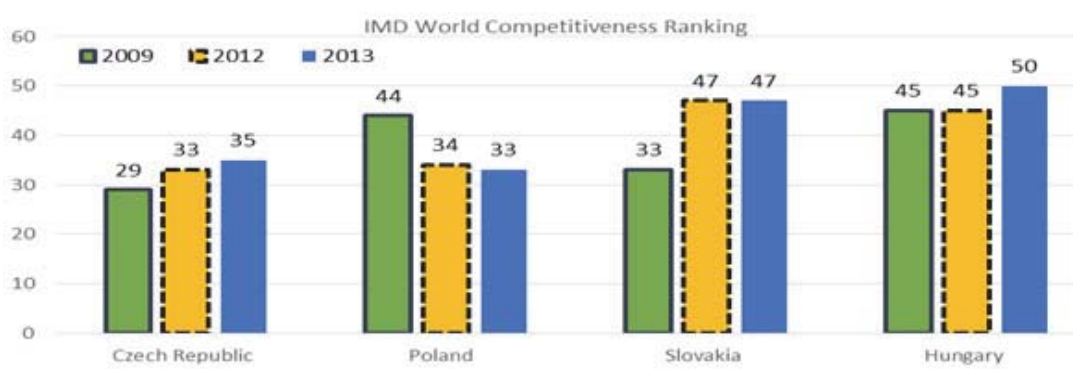

Figure 1: IMD World Competitiveness Ranking ${ }^{4}$ (2009-2013)

Source: Authors' Analysis Based on IMD, 2013

Competitiveness is referred as the ability of a firm or nation to generate more wealth for its owners or citizens than its competitors in the global marketplace (Salvatore, 2010). The Czech economy is being stimulated by global changes to search for its competitive advantage by improving on production standards (Nečadova and Scholleová, 2011). Figure 1 and table 1 show the competitiveness ranking in the Czech Republic and some countries. Figure 1 shows a sharp decline of the Czech Republic in the world competitiveness ranking from 29 position in 2009 down to 35 position between in 2013. This decline might be connected with the recent economic meltdown. However, Poland's position improved from 44th position in 2009 up to 33rd position in 2013, surpassing the Czech Republic, Slovakia and Hungary in the same period under study.

Table 1: Pillars of the GCl: Czech Republic and Poland (2010-2014)

\begin{tabular}{|c|c|c|c|c|c|c|c|c|}
\hline \multirow{3}{*}{$\begin{array}{l}\text { Pillars of the Global } \\
\text { Competitiveness Index }\end{array}$} & \multicolumn{4}{|c|}{ Czech Republic } & \multicolumn{4}{|c|}{ Poland } \\
\hline & \multicolumn{2}{|c|}{ 2010-2011 } & \multicolumn{2}{|c|}{ 2013-2014 } & \multicolumn{2}{|c|}{$2010-2011$} & \multicolumn{2}{|c|}{ 2013-2014 } \\
\hline & $\begin{array}{c}\text { Rank } \\
\text { (out of 139) }\end{array}$ & $\begin{array}{c}\text { Index } \\
(1-7)\end{array}$ & $\begin{array}{c}\text { Rank } \\
\text { (out of 148) }\end{array}$ & \begin{tabular}{|c|} 
Index \\
$(1-7)$
\end{tabular} & $\begin{array}{c}\text { Rank } \\
\text { (out of 139) }\end{array}$ & $\begin{array}{c}\text { Index } \\
(1-7)\end{array}$ & $\begin{array}{c}\text { Rank } \\
\text { (out of 148) }\end{array}$ & \begin{tabular}{|c|} 
Index \\
$(1-7)$
\end{tabular} \\
\hline Global Competitiveness Index & 36 & 4.6 & 46 & 4.4 & 39 & 4.5 & 42 & 4.5 \\
\hline Basic requirements & 44 & 4.9 & 55 & 4.8 & 56 & 4.7 & 59 & 4.7 \\
\hline Pillar 3: Macroeconomic environment & 48 & 4.9 & 55 & 5.0 & 61 & 4.7 & 65 & 4.9 \\
\hline Efficiency enhancers & 28 & 4.7 & 37 & 4.5 & 30 & 4.6 & 32 & 4.6 \\
\hline Pillar 6: Goods market efficiency & 35 & 4.6 & 48 & 4.4 & 45 & 4.4 & 57 & 4.3 \\
\hline Pillar 10: Market size & 42 & 4.5 & 41 & 4.5 & 22 & 5.2 & 20 & 5.1 \\
\hline Foreign market size index, 1-7 (best) & 28 & - & 28 & 5.5 & 22 & - & 22 & 5.7 \\
\hline Innovation/ sophistication factors & 30 & 4.2 & 36 & 4.1 & 50 & 3.8 & 65 & 3.7 \\
\hline Pillar 12: Innovation & 22 & 5.4 & 37 & 3.7 & 50 & 4.2 & 65 & 3.2 \\
\hline
\end{tabular}

Source: WEF Global Competitiveness Index (GCI), 2011 and 2013

\section{Data and Analytical Framework}

\subsection{Data Description and Sources}

Annual time-series economic data, spanning from 1993 to 2012, was used during the course of this study. Our sample size is dictated by the fact that Czech Republic became a new independent state in January, 1993. The selected variables comprise market size - proxied by real GDP per capita (expressed in US\$), inward FDI (expressed as a proportion of GDP), globalization index (proxy for globalization), trade openness (trade as a proportion of GDP), and real effective exchange rate (REER) -CPI-based.

All the available data used in the course of this study were transformed into the natural logarithm form. Moreover,

${ }_{4}^{4}$ IMD World Competiveness ranking covered 60 advanced and emerging economies. The ranking ranges from 1-60 with 1 as the best ranking while 60 as the worst ranking in the world in terms of competiveness. 
all the secondary data were retrieved from the online databases of UNCTADSTAT, World Bank world development indicators, and ETH KOF Index of Globalization (Dreher, 2006; Dreher et al., 2008). All the data were processed using two econometric software - Stata/SE 12. 0 and JMUITi.

\subsection{Analytical Framework}

Given that the main purpose of this paper is to look at the dynamic interactions between the Czech Republic market size and macroeconomic variables in the era of present day globalization. We chose to adopt the Vector Autogresssive (VAR) model for our work. For the purpose of this work, the baseline VAR model equations are specified below:

I_Real_GDP_per_capita $=\mathrm{f}($ I_Inward_FDI_of_GDP_, I_Trade_openness, I_REER_CPI_, I_Global_Index) (1)

I_Inward_FDI_of_GDP_ = f(I_Real_GDP_per_capita, I_Trade_openness, I_Global_Index, I_REER_CPI_) (2)

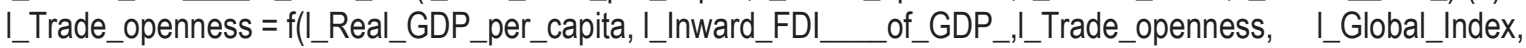
I_REER_CPI_)

I_REER_CPI_ $=$ f(I_Real_GDP_per_capita, I_Inward_FDI_of_GDP_, I_Trade_openness, I_Global_Index) (4)

I_Global_Index = f(I_Real_GDP_per_capita, I_Inward_FDI_of_GDP_, I_Trade_openness, I_REER_CPI_) (5)

Where I_Real_GDP_per_capita is the logarithm of real GDP per capita, I_Inward_FDI__of_GDP_ is the logarithm of inward FDI, I_Trade_openness is the logarithm of trade openness, I_REER_CPI_is the logarithm of real effective exchange rate, and I_Global_Index is the logarithm of globalization index.

The choice of this method was more or less necessitated on the time series properties of the selected variables. The origin of the VAR model can be traced to the works of Christopher Sims in 1980. In the VAR model, all variables are assumed to be endogenous, though; exogenous variables, as well as deterministic terms, could still be added to the model. The generalized VAR model is presented as:

$\mathrm{Y}_{\mathrm{t}}=\boldsymbol{\alpha}_{\boldsymbol{t}}+\sum_{\boldsymbol{i}=\mathbf{1}}^{\boldsymbol{n}} \boldsymbol{\beta}_{\boldsymbol{i}} \boldsymbol{Y}_{\boldsymbol{t}-\boldsymbol{i}}+\boldsymbol{\delta} \boldsymbol{X}_{\boldsymbol{t}}+\boldsymbol{\mu}_{\mathrm{t}}$ (6)

Recall that, $Y_{t}$ is the vector of observed endogenous variables (I_Real_GDP_per_capita, I_Inward_FDI_of_GDP_, I_Trade_openness, I_REER_CPI_, I_Global_Index), whereas, $\boldsymbol{X}_{\boldsymbol{t}}$ is a vector of observed exogenous variables, $\boldsymbol{\alpha}_{\boldsymbol{t}}$ represents deterministic terms and/or dummy variables (in this instance, $\boldsymbol{\alpha}_{\boldsymbol{t}}$ is a KX 1 vector of intercept term); $\mu$ is a vector of residuals, and it is expected that the residuals are independent, identically distributed (iid). $\boldsymbol{\beta}_{\boldsymbol{i}}$ and $\boldsymbol{\delta}$ are parameter matrices that would be estimated from the model.

The reduced-form of the model as used in this study does not incorporate an exogenous variable. We assume that all the variables used in the model are all endogenous. Prior to the model estimation, we shall investigate the stationarity of the time series using two conventional unit root tests - Kwiatkowski-Phillips-Schmidt-Shin (KPSS) and Phillips-Perron (PP) tests.

All other things being equal; the findings from the VAR model would be used to check for Granger (non) causality (Granger, 1969). Given that the interpretations of the generalized VAR model are complicated and so makes it jejune to make any meaningful economic deductions, further analysis of the estimated VAR model would incorporate the Cholesky innovation accounting (OIRF - Orthogonalized Impulse Response Function) technique. In general, the impulse response function traces the dynamic time path of a given variable in response to a shock on itself and other variables within an estimated model (Kumar, 2011).

The innovation accounting for OIRF relies heavily on a priori economic theory or assumptions for the causal order of the variables in the VAR model using the technique of Cholesky triangularization of estimated variance-covariance matrix of the reduced-form error terms. Thus, it is expected that innovations within the model are uncorrelated with one another (Krznar and Kunovac, 2010; Caggiano et al., 2012).

For the purpose of this work, the choice of the ordering of the variables would be based on our economic intuition of the interactions of the variables within the context of the Czech Republic as well as drawn inference from the Granger (non) causality test. In certain situations, we would equally have to be flexible in terms of alternative orderings of the variables so as to investigate the robustness of our results.

\subsection{Pre-Estimation Technique}

\subsubsection{Stationarity (Unit Root) Test}

In accordance with econometric principles based on time-series data, it is always advantageous to check the stationarity of time series data. As posited by Gujarati (2003), the use of non-stationary time series data is tantamount to spurious regression. Hence, such regression result validity is not tenable. Table 2 presents the results of both PP and KPSS unit 
root tests.

As can be seen from the table (see table 2), Inward FDI, which is expressed as a percentage of GDP and Globalization Index, are both stationary at levels, i.e., I (O). The other variables- real GDP per capita, trade openness and real effective exchange rate are stationary in their first differences. Based on the findings from the unit root test, we decided to adopt the VAR model to estimate the model. All the transformed variables would be used in the model based on their assumed order of integration while the other two variables would equally be entered into the VAR model as I (0) variables.

Table 2: Stationarity Test

\begin{tabular}{llccl}
\hline Variable & Level/ First Difference & PP Test & KPSS Test & Inference \\
\hline \multirow{2}{*}{ I_Real_GDP_per_capita } & Level & -1.229 & 0.7433 & Non-stationary \\
& First Difference & $-2.690^{*}$ & $0.1392^{* * *}$ & Stationary \\
I_Inward_FDI_of_GDP_ & Level & $-3.101^{* *}$ & $0.1609^{* * *}$ & Stationary \\
& First Difference & $\mathrm{N} / \mathrm{A}$ & $\mathrm{N} / \mathrm{A}$ & $\mathrm{N} / \mathrm{A}$ \\
I_Trade_openness & Level & -0.724 & 0.7021 & Non-stationary \\
& First Difference & $-4.766^{* *}$ & $0.1010^{* * *}$ & Stationary \\
I_REER_CPI_ & Level & -1.300 & 0.7576 & Non-Stationary \\
& First Difference & $-6.244^{* * *}$ & $0.0990^{* * *}$ & Stationary \\
I_Global_Index & Level & $-5.623^{* * *}$ & $0.0000^{* * *}$ & Stationary \\
& First Difference & $\mathrm{N} / \mathrm{A}$ & $\mathrm{N} / \mathrm{A}$ & N/A \\
\hline
\end{tabular}

Note: The asterisks $\left({ }^{*},{ }^{* *},{ }^{* * *}\right)$ denote stationarity at $10 \%, 5 \%$, and $1 \%$ respectively.

\subsubsection{Lag Length Selection}

One of the key assumptions of the VAR model is the selection of the appropriate lag length for the model. The model selection is usually computed using an information criterion method. Based on the evidence provided by the information criterion, we chose two lags as the optimal lag length (see appendix A).

\section{Empirical Results and Interpretation}

Having satisfied, a priori econometric condition, we set out to estimate a system of five equation VAR model. A look at table 3 shows that each of the five equations within the VAR model is statistically significant at the 0.01 level. The coefficient of determination (R-squared) for the five equation model is between 0.60 and 0.99 , this shows that at least $60 \%$ of the variation within the model is accounted for by the included variables in the VAR model. The full results of the estimated baseline VAR model were omitted due to brevity of space.

Table 3: VAR Model Overview

\begin{tabular}{|c|c|c|c|c|c|c|}
\hline Sample: & 12 & & & No. & $a b s$ & $=$ \\
\hline Log likelihood $=$ & 206.4329 & & & AIC & & $=-16.82588$ \\
\hline FPE & $9.18 e-14$ & & & $\mathrm{HQIC}$ & & $=-16.45074$ \\
\hline $\operatorname{Det}\left(\right.$ Sigma_ml $\left._{1}\right)$ & $7.52 e-17$ & & & SBIC & & $=-14.1053$ \\
\hline Equation & Parms & RMSE & $R-s q$ & chiz & P>chiz & \\
\hline 1_Inward_FDI_ - & 11 & .653423 & 0.6281 & 30.40311 & 0.0007 & \\
\hline 1_Global_Index & 11 & .009289 & 0.9895 & 1702.513 & 0.0000 & \\
\hline d_I_Real_GDP_P a & 11 & .023291 & 0.7599 & 56.98176 & 0.0000 & \\
\hline d_I_Trade_open $=$ & 11 & .046363 & 0.8222 & 83.21984 & 0.0000 & \\
\hline d_1_REER_CPI_ & 11 & .048553 & 0.6043 & 27.48372 & 0.0022 & \\
\hline
\end{tabular}

\subsection{Model Diagnostic (Robustness) Checklist}

Moreover, prior to using the VAR model for the purpose of predictability (Granger Causality), it is always best practices within the domain of econometric analysis to subject the estimated model to some relevant diagnostic tests in order to be sure of the robustness of the estimated VAR model. The Jarque-Bera test for normality of residuals indicates that all the residuals are normally distributed (see table 4). 
Table 4: Jarque-Bera Test for Normality of Residuals

\begin{tabular}{lcc}
\hline Variable (Residual) & Test stat & P-Value (Chi^2) \\
\hline u1 (Equation 1) & 1.9513 & 0.3770 \\
u2 (Equation 2) & 0.5702 & 0.7519 \\
u3 (Equation 3) & 1.0472 & 0.5924 \\
u4 (Equation 4) & 0.5653 & 0.7538 \\
u5 (Equation 5) & 0.5509 & 0.7592 \\
\hline
\end{tabular}

Also, using the joint test statistic of Doornik and Hansen $(\mathrm{DH})$, the null hypothesis that residuals are multivariate normally distributed cannot be rejected given that the $p$-value $(0.63)$ is much higher than the 0.05 level (see appendix B). Moreover, the results of the autoregressive conditional heteroscedasticity (ARCH) test, confirm the absence of ARCH effect of the estimated VAR model, and this is as depicted in appendix $C$. The residuals from the estimated VAR model do not have any ARCH errors. The same conclusion is equally true using the multivariate ARCH-LM TEST with 1 lags, with a VARCHLM test statistic of 240.04, p-value (chi^2) - 0.23, and degrees of freedom - 225.00 .

The dynamic stability of the estimated VAR model is as presented in appendix D. By and large, the estimated model is dynamically stable given that the roots (eigenvalues) of the parameter estimates are all inside the unit circle.

\subsection{Granger Causality}

Based on the Granger causality test, we are able to explore unidirectional relationships, bidirectional (feedback mechanism) relationships, as well as the absence of any causality amongst the selected variables in the model. The result of the Granger causality test is presented in table 7. The results obtained from the table (see table 7) show a unidirectional causality emanating from the KOF globalization index (significant at the 0.05 level) as well as growth in real GDP per capita (proxy for market size) to inward FDI (significant at the 0.10 level). This result shows that the more globalized the Czech economy becomes, the more in the future; it would continually attract inward FDI given that previous scores of the globalization index significantly influence the inflow of FDI.

Based on the findings, it is plausible to state that the result is in tandem with the findings of Choe, 2003; Leitao, 2012; Ho et al., 2013. Similarly, there is evidence of a unidirectional Granger causality running from globalization to market size, and it is significant at the 0.01 level. Also, there is a unidirectional causality running from inward FDI to trade openness (significant at the 0.10 level). In the same vein, inward FDI seems to 'Granger cause' real effective exchange rate (significant at the 0.05 level). The findings parallel some earlier works by (Dreher, 2003; Al-mulali and Sab, 2009; Adamkiewicz-Drwillo, 2012; and Gurgul and Lach, 2014).

Further evidence shows bidirectional causality between trade openness with market size. Trade openness and real GDP per capita (proxy for market size) have bidirectional causality; it appears there is a 'strong' Granger causality between the two variables (significant at the 0.01 level). The findings tally with some previous empirical works such as Gries and Redlin (2012), Hossain and Mitra (2013), and Zeren and Ari (2013).

The same bidirectional relationship is equally true of real effective exchange rate and market size of the Czech economy. In this instance, both the real effective exchange rate and real GDP per capita 'Granger cause' each other and it is significant at the 0.01 level. Similar results were equally reported by some studies (Odhiambo, 2011; Aliyu, 2009).

However, each of the variables in the model does not appear to Granger cause globalization index), but when taken as a whole, it is obvious they 'Granger cause' globalization (significant at the 0.01 level). The findings are a pointer to the fact that globalization is an evolving process and an aggregation of dynamic, interrelated factors.

Hence, a single socioeconomic factor is infeasible in the predictability of how globalized an economy is in comparison to the rest of the globe. Arguably, this provides ample evidence that the rate of globalization of the Czech economy is not only influenced by socioeconomic factors, but also impacted upon by global politicking and alliances. Apparently, there is a Granger non - causality between globalization index and trade openness as well as between globalization index and real effective exchange rate. Arguably, we may wish to state that since the Czech Republic is still undergoing major economic transformation, it could be 'soonest' that the impact of globalization would begin to take effect on both trade openness and the real effective exchange rate and vice versa. 
Table 7: Granger Causality Wald Tests

\begin{tabular}{|c|c|c|c|c|}
\hline Equation & Ixcluded & $c h 12$ & $d=$ & $P=a b>a n 12$ \\
\hline 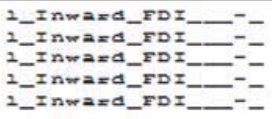 & 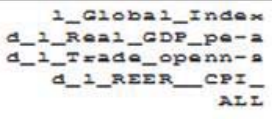 & $\begin{array}{l}6.3999 \\
5.5616 \\
.63033 \\
2.3709 \\
26.381\end{array}$ & $\begin{array}{l}2 \\
2 \\
2 \\
2 \\
8\end{array}$ & $\begin{array}{l}0.042 \\
0.062 \\
0.730 \\
0.306 \\
0.001\end{array}$ \\
\hline 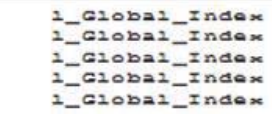 & 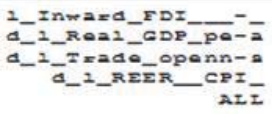 & $\begin{array}{l}3.4691 \\
1.6165 \\
1.0872 \\
2.4306 \\
22.155\end{array}$ & $\begin{array}{l}2 \\
2 \\
2 \\
2 \\
8\end{array}$ & $\begin{array}{l}0.276 \\
0.446 \\
0.381 \\
0.297 \\
0.005\end{array}$ \\
\hline 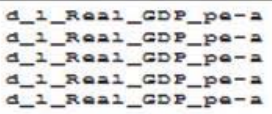 &  & $\begin{array}{l}1.6202 \\
9.3067 \\
17.862 \\
12.318 \\
42.712\end{array}$ & $\begin{array}{l}2 \\
2 \\
2 \\
2 \\
8\end{array}$ & $\begin{array}{l}0.445 \\
0.010 \\
0.000 \\
0.002 \\
0.000\end{array}$ \\
\hline 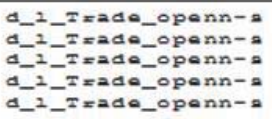 & 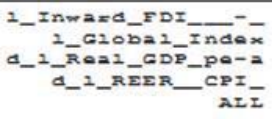 & $\begin{array}{r}5.2346 \\
3.662 \\
28.298 \\
27.082 \\
64.72\end{array}$ & $\begin{array}{l}2 \\
2 \\
2 \\
2 \\
8\end{array}$ & $\begin{array}{l}0.073 \\
0.160 \\
0.000 \\
0.000 \\
0.000\end{array}$ \\
\hline 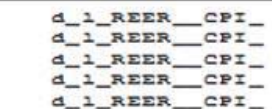 & 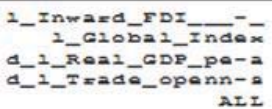 & $\begin{array}{l}6.9982 \\
2.0975 \\
15.359 \\
1.2439 \\
20.328\end{array}$ & $\begin{array}{l}2 \\
2 \\
2 \\
2 \\
8\end{array}$ & $\begin{array}{l}0.030 \\
0.578 \\
0.000 \\
0.537 \\
0.009\end{array}$ \\
\hline
\end{tabular}

\subsection{Innovation Accounting}

The generalized VAR model provides much more insightful ways of looking at the impulse responses of variables within an estimated model. Prior to generating the OIRF, we decided to do a reordering of the initial estimated VAR to reflect some of our assumptions. Thus, the new ordering becomes: I_Global_Index, I_Inward_FDI__of_GDP_, I_REER_CPI_, I_Trade_openness, and I_Real_GDP_per_capita.

\subsubsection{Orthogonal Impulse Response Function (OIRF) Analysis}

Due to brevity of space, we shall only consider the OIRF of some of the selected variables as shown in figure 2 . The $95 \%$ Hall Percentile confidence interval was generated using a bootstrap simulation of 5000 replications. The findings from OIRF are as shown in figure 2.

As depicted in panel A (see figure 2), the initial shock to trade openness on real GDP per capita is positive and statistically significant, and afterwards decline significantly till the next one year and remains almost flat until the third year. Real GDP per capita starts showing signs of improvement in the third year and eventually becomes statistically significant while peaking in the fifth year and thereafter start shrinking. The deduction from panel B (see figure 2) shows that real GDP per capita is positively connected to the shock in globalization index both in the short-term and long-term. In the medium term, GDP per capita might experience a slight dip due to a shock in the globalization index, but rebounds in the long-run and it is apparent that the result is statistically significant.

In panel C (see figure 2), the initial shock emanating from globalization index to inward FDI is equally positive and statistically significant but thereafter declines within the next two-year time horizon. Even though inward FDI is positive in the third year, the shock to globalization index would eventually lead to a fall of inward FDI in the fourth year and finally converges afterwards to a null effect.

From panel D (see figure 2), it appears that the shock to inward FDI has a 'cyclical' effect on the real effective exchange rate. First, it is initially negative and then becomes positive (statistically significant) in the first year and thereafter becomes negative (statistically significant) in the second year. Similar picture of the cyclical nature response of the real effective exchange rate to a shock on inward FDI seems to be repeated over time.

As can be seen from Panel $\mathrm{E}$ (see figure 2), it is evident to state that an innovation to real GDP per capita would be of no effect to trade openness in the initial period but subsequently becomes positive during the first period. Within the next two years ahead, response of trade openness to the shock in real GDP per capita is negative and statistically significant. Eventually, it starts rising afterwards and peaks in the fifth period and ultimately starts shrinking. In general, the last Panel (see figure 2) shows that a shock to inward FDI is positively connected to trade openness and apparently converges in the sixth year. Although, there was a significant dip in the second year, trade openness still rose and significantly peaked in the fifth year due to the shock in inward FDI. 
Figure 2: OIRF (Response to Cholesky One S.D. Innovations)



\section{Concluding Remarks}

This paper utilizes the Granger causality test, impulse response function and variance decomposition methods in an attempt to explore the interactions of the Czech Republic market size (real GDP per capita), trade openness, inward FDI, real effective exchange rate and globalization dynamics. The results of the empirical study provide evidence that globalization (proxied by globalization index) is a strong incentive for more inward FDI into the Czech Republic. Further results equally show that the more globalized the Czech economy becomes, so would the Czech economy experience both short-term and long-term growth in real GDP per capita.

Moreover, results from the Granger causality test indicated a feedback relationship between market size and trade openness as well as between market size and real effective exchange rate. There is equally a unidirectional relationship between FDI and market size; it indicates that inward FDI attraction to the Czech Republic does not only hinge on globalization alone, but also due to the Czech market size in terms of real GDP per capita growth. In a similar fashion, there is suggestive evidence that inward FDI promotes trade openness. This implies that the more inflow of FDI into the Czech economy, the more trading channels that would be developed in terms of exports and imports of goods and services with the rest of the world. Also, fluctuations in foreign capital inflow in terms of inward FDI appear to have a robust impact on the real effective exchange rate. The results of the findings equally show a unidirectional relationship running from real effective exchange rate to trade openness.

By and large, the findings from this study provide robust evidence that globalization fosters market size (real GDP per capita) growth within the context of the Czech economy. It is equally imperative to state that globalization appears to 
be a sine qua non for more inward FDI in the Czech Republic, and there is seemingly a transmission channel running from globalization to both trade openness and real effective exchange rate through inward FDI.

\section{References}

Adamkiewicz-Drwillo, H. G. (2012). Estimating the impact of globalization on international competitiveness: A multidimensional approach. China-USA Business Review, 11(12), 1543-1556.

Al-mulali, U., \& Sab, N. C. (2009). The impact of oil prices on the real exchange rate of the Dirham: a case study of the United Arab Emirates. OPEC Energy Review, 35(4), 384-399.

Aliyu, S.U. R. (2009). Impact of oil price shock and exchange rate volatility on economic growth in Nigeria: An empirical investigation. Research Journal of International Studies, 11, 4-15.

Bretschger, L., \& Hettich, F. (2005). Globalization and international tax competition: empirical evidence based on effective tax rates. Journal of Economic Integration, 20(2), 530-542.

Caggiano, G., Castelnuovo, E., \& Groshenny, N. (2012). Policy uncertainty shocks and labor market dynamics in the U.S. Reserve Bank of New Zealand Preliminary Paper. $19 \mathrm{pp}$.

Choe, J. I. (2003). Do foreign direct investment and gross domestic investment promote economic growth? Review of Development Economics, 7(1), 44-57.

Dreher, A. (2003). Does globalization affect growth? Mannheim. The University of Mannheim Working Paper. http://dx.doi.org/10.2139/ssrn.348860.

Dreher, A. (2006). Does Globalization affect growth? Evidence from a new index of globalization. Applied Economics, 38(1), 1091-1110.

Dreher, A., Gaston N., \& Martens, P. (2008). Measuring globalization - gauging its consequences. Berlin: Springer.

Gorodnichenko, Y., Svejnar, J., \& Terrell, K. (2008). Globalization and innovation in emerging markets. Research Seminar in International Economics Discussion Paper No. 583.

Gries, T., \& Redlin, M. (2012). Trade openness and economic growth: a panel causality analysis. Center for International Economics, University of Paderborn Working Paper No. 2011-06.

Granger, C. W. (1969). Investigating causal relationships by econometric models and cross-spectral models. Econometrica, 16, 121-130.

Gurgul, H., \& Lach, Ł. (2014). Globalization and economic growth: evidence from two decades of transition in CEE. Economic Modelling, 36, 99-107. DOI: 10.1016/j.econmod.2013.09.022.

Hlaváček, P., \& Olšová, P. (2011). Impact of globalization and foreign direct investment on the regional economies: The case of the Czech Republic, in the Scale of Globalization. Think Globally, Act Locally, Change Individually in the 21st Century. Ostrava: University of Ostrava, pp. 70-75.

Hossain, S., \& Mitra, R. (2013). The determinants of economic growth in Africa: a dynamic causality and panel cointegration analysis. Economic Analysis and Policy, 43(2), 217-226.

Jindcichovska, I. (2012). Funding innovations in globalized world: the Czech approach. Research Journal of Economics, Business and ICT, 4, $19-24$.

Krznar, I., \& Kunovac, D. (2010). Impact of external shocks on domestic inflation and GDP. Croatian National Bank Working Papers W26.

Kumar, T. A. (2011). Energy consumption, $\mathrm{CO}_{2}$ emissions and economic growth: a revisit of the evidence from India. Applied Econometrics and International Development, 11(2), 165-189.

Lee, E.S. (2004). Anti-competitive practices as trade barriers used by Korea and Japan: focusing on service and investment markets. Bound Law Review, 16(1), 117-165.

Lee, J. (2010). Globalization and business cycle synchronization: evidence from the United States. Journal of International and Global Economic Studies, 3(1), 41- 59.

Leitao, N.C. (2012). Foreign direct investment and globalization. Actual Problems of Economics, 130, 398-405.

Marek, D. and Baun, M. (2010). The Czech Republic and the European Union. London: Routledge: Taylor and Francis Group.

Nečadova, M., \& Scholleová, H. (2011). Motives and barriers of innovation behavior of companies. Economics and Management, 16, 832-838.

Nečadova, M., \& Scholleová, H. (2012). Competitiveness and innovation performance of the Czech Republic in international rankings. Research Journal of Economics, Business and ICT, 4, pp. 52-57.

Ocampo, J. A. and Martin, J. (2003). Globalization and development: A Latin American and Caribbean perspective (Eds). Stanford, CA: Stanford University Press.

Odhiambo, N. M. (2011). Tourism development and economic growth in Tanzania: empirical evidence from the ARDL- bounds testing approach. Economic Computation \& Economic Cybernetics Studies \& Research, 45(3).

OECD (2008): Benchmark Definition of Foreign Direct Investment, 4th Ed. Paris: OECD Publishing.

Gujarati, D.N. (2003). Basic econometrics (4th Ed.). New York: McGraw Hill Higher Education.

Salvatore, D. (2010). Globalization, international competitiveness and growth: advanced and emerging markets, large and small countries. Journal of International Commerce, Economics and Policy, 1(1), 21-32.

Sims, C. A. (1980). Macroeconomics and reality. Econometric Society, 48(1), 1-48.

Stiglitz, J. E., and Charlton, A. (2007): Fair trade for all: how trade can promote development (Rev. Ed.). New York: Oxford University Press. 
UNCTADSTAT (2013). World statistical database. Geneva: United Nations

World Bank (2013). World development indicators. Washington: World Bank.

World Economic Forum (2010). The global competitiveness report 2010-2011. Geneva: World Economic Forum.

World Economic Forum (2013). The global competitiveness report 2012-2013. Geneva: World Economic Forum.

Yun, M. (2004). Competition and productivity growth: evidence from Korean manufacturing firms, in UNCTAD No. UNCTAD/DITC/CLP/2004/1. Geneva: United Nations Publications, pp. 251-264.

Zeren, F., \& Ari, A. (2013). Trade openness and economic growth: a panel causality Test. International Journal of Business and Social Science, 4(9), 317-324.

Appendix A: VAR Model Lag Length Selection Using Information Criterion

\begin{tabular}{|c|c|c|c|c|c|c|c|c|}
\hline lag & II & IR & $d f$ & P & FPE & AIC & HQIC & SBIC \\
\hline 0 & 101.618 & & & & $1.5 e-11$ & -10.7354 & -10.7013 & -10.488 \\
\hline 1 & 162.146 & 121.06 & 25 & 0.000 & $3.3 e-13$ & -14.6829 & -14.4783 & -13.199 \\
\hline 2 & 206.433 & $88.573^{\circ}$ & 25 & 0.000 & $9.2 \mathrm{e}-14 t$ & $-16.8259^{\circ}$ & -16.4507. & $-14.1053^{4}$ \\
\hline
\end{tabular}

Appendix B: Doornik and Hansen Multivariate Normality of Residuals Test

\begin{tabular}{|l|c|}
\hline Joint test statistic & 7.9523 \\
\hline P-value & 0.6335 \\
\hline Degrees of freedom & 10.0000 \\
\hline Skewness only & 6.7370 \\
\hline P-value & 0.2409 \\
\hline Kurtosis only & 1.2153 \\
\hline P-value & 0.9434 \\
\hline
\end{tabular}

Appendix C: ARCH-LM TEST with 2 Lags

\begin{tabular}{ccccc}
\hline Residual & Test-Stat & P-Value $\left(\mathrm{Chi}^{\wedge}\right.$ 2) & F-stat & P-Value (F) \\
\hline $\mathrm{U}_{1}$ & 2.1426 & 0.3426 & 1.2370 & 0.3223 \\
$\mathrm{U}_{2}$ & 1.9479 & 0.3776 & 1.1090 & 0.3592 \\
$\mathrm{U}_{3}$ & 0.5616 & 0.7552 & 0.2910 & 0.7523 \\
$\mathrm{U}_{4}$ & 4.0032 & 0.1351 & 2.6695 & 0.1068 \\
$\mathrm{U}_{5}$ & 0.6928 & 0.7072 & 0.3621 & 0.7030 \\
\hline
\end{tabular}

Source: Own Work

Appendix D: Roots of the Companion Matrix of Estimated VAR Model

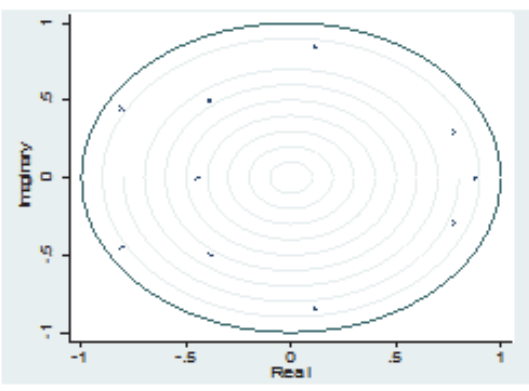

Source: Own Work 